\title{
Research Article Comparing Undergraduates' Connection with Nature and New Ecological Paradigm in Relation to Intention of Environmental Behaviors in Taiwan and Japan
}

\author{
Yu Chi Tseng*, Ryo Sakurai**, Kimiharu To*** \\ National Taichung University of Education, Taiwan* \\ Ritsumeikan University** \\ Aomori University*** \\ Accepted on November 5, 2021
}

\begin{abstract}
Connection with nature (CWN) is a promising research focus in environmental education. Previous research has repeatedly indicated that CWN was an important predictor of proenvironmental behaviors. Therefore, the purpose of this research was to understand the difference of Taiwanese and Japanese undergraduates' CWN and most importantly to compare the predictive power of CWN and the new ecological paradigm (NEP) in terms of explaining the intention of environmental behaviors (IEB) in both countries. This survey adopted one Taiwanese CWN scale to avoid possible measurement bias caused by eastern-western cultural contexts. A total of 302 undergraduates participated in this survey: 178 students were from 3 Taiwanese universities, and 124 were from 2 Japanese universities. The independent sample t-test showed that Taiwanese undergraduates significantly performed more actively in CWN, NEP, and IEB than Japanese undergraduates. The overall findings of multiple regression analysis indicated that CWN was a more powerful predictor than the NEP to predict the IEBs in both countries, and the regression coefficient of CWN in Taiwan was higher than in Japan. Although the NEP can significantly predict some IEB constructs in Taiwan, it was not a significant predictor in Japan. Based on those findings, this research also proposed possible directions for future research.
\end{abstract}

Keywords: connection with nature; cross-country survey, new ecological paradigm, intention of environmental behavior, undergraduate students

\section{Introduction}

Since 1980, a series of research on Significant Life Experiences (SLEs) has indicated nature experiences in childhood and adolescence as one of the most formative experiences that could influence people's environmental commitments and actions (Chawla and Derr 2012, Cagle 2018). When Louv (2005) created the term "nature-deficit disorder" to describe children and adolescents' health problems due to the alienation from nature in the U.S., the benefits of connecting with nature (CWN) caught environmental educators' attention to the cultivation of learners' positive relationships with nature. $\mathrm{CWN}$ also led a new trend in environmental education (EE) research to bring nature back into the theoretical frameworks, which was initially not an important factor in previous theoretical 
models (e.g., the Responsible Environmental Behavior model proposed by Hines et al. in 1987).

$\mathrm{CWN}$ is an internalized awareness of one's interrelatedness with nature in several psychological dimensions. Some scholars viewed CWN as a specific emotion or cognition toward nature. For example, Kals et al. (1999) believed CWN was a purely emotional concept and defined it as people's emotional inclination to nature that comprised love, freedom, safety, and oneness to nature. For Schultz and Clayton, CWN was a cognitive concept of self-identification with nature. Schultz (2002) tended to measure the extent to which an individual included nature within his/her cognitive representation of the self. Similarly, Clayton (2003) viewed CWN as an environmental identity and a belief that the environment is important to us and an important part of who we are. In recent years, more and more researchers, such as Nisbet et al. (2009) and Zylstra et al. (2014), are inclined to consider CWN a holistic concept that might simultaneously comprise affect, cognition, identity, perspective, belief, experience, and even spirituality. For instance, Nisbet et al.'s Nature Relatedness Scale was a typical instrument that took this multidimensional viewpoint to measure experience, the self, and perspective about nature.

Considering the CWN-EB association, several studies have shown that CWN can significantly predict environmental behavior (EB) - including intention and frequency of various behaviors) no matter what CWN scales were adopted. For instance, Kals et al. (1999) found that the emotional CWN (emotional affinity toward nature) could significantly predict 281 German adults' personal behavioral decisions. Nisbet et al. (2009) discovered that CWN can predict 145 Canadian undergraduates' participation in environmental organizations and green consumption. When Tam (2013) compared the predictive power of the seven CWN scales to EB, he found that the common component of these seven CWN scales can significantly explain 322 Hong Kong undergraduates' and 186 American adults' EB, like energy-saving and green consumption. Recently, a survey conducted by Whitburn et al. (2019) in Wellington confirmed that CWN was the strongest predictor of 423 New Zealand adults' energy-saving, recycling, and conservation support.

However, most CWN definitions and scales were created in western cultural contexts (Zylstra et al. 2014). Recent papers also showed that scale invariance might be problematic when testing American CWN scales in European countries (Olivos et al. 2011; Pasca et al. 2018). Moreover, most research was conducted to test the relationships among $\mathrm{CWN}$, environmental attitude (EA), and EB in North America and Europe. All the situations mentioned above may cast doubt on whether the CWN scales and research findings can also be applied to other cultural contexts due to intellectual sensitivity between eastern and western cultures that has been illustrated in contemporary philosophical and psychological inquiries.

To overcome the possible cultural bias, the first author of this article initiated a series of CWN research in Asian contexts. Tseng first redefined the CWN concept from Taiwanese adolescents' experiences and perspectives and found that cognitive knowledge did not lead to CWN. In addition, unlike what western research has found, Taiwanese adolescents lacked a spiritual dimension in their CWN. Therefore, a revised CWN definition was proposed to fit the Taiwanese cultural context better. For Taiwanese adolescents, CWN meant "a developing inner union of the self with nature that comprises multiple sensory engagements in nature with subsequent rich positive and negative emotions attached to nature. Through reflection or guidance, sensory and 
emotional CWN could be transformed and integrated into a personal value system related to nature in general as a symbolic CWN" (Tseng and Wang 2020, p. 13). Based on these findings, Tseng (2019) designed a CWN scale that comprised three constructs-sensory experiences, psychological benefits, and the importance of nature. Tseng (2020) then adopted this adolescent CWN scale to further explore the relationships among teenagers' SLE, CWN, and EBs and finally verified that $\mathrm{CWN}$ was the most powerful predictor to EBs. CWN not only can directly and significantly predicted EBs, it also mediated the influence of SLEs on EBs (mediation effect).

Given the fact that CWN has become a powerful motivator to EBs, it might be the time to compare the predictive power of the factors that were assumed effectively influencing EBs in the past research. Among those factors, NEP was one of the most widely used concept and scale that represented an individual environmental attitude by measuring his or her"primitive beliefs" of "seeing the world ecologically" (Dunlap, Van Liere, Mertig and Jones 2000). Therefore, we thought NEP was appropriate target to be compared with. Another reason for this CWN-NEP comparison emerged from the practical needs for both efficient educational interventions and behavioral change to cope with urgent environmental problems. Considering that environmental attitude (like NEP) were implicitly formed by family, schools, (social) media, or organizations through one's lifetime, it is really challenging to identify which factor or life stage that was most influential to people's environmental attitude leading to EBs. In contrast, if we can prove that CWN was a better predictor than NEP, then we could point out a "natural short cut" to encourage people's EBs by reconnecting them with nature through outdoor programs or curricula in nature.

To date, there are not many published papers revealing how CWN influenced people's EB in Asia, neither did these articles compared the influential level of CWN and NEP to EBs. Accordingly, this research aims to firstly present the current situation and the difference in CWN among demographic features and between countries (Taiwan and Japan). Secondly and most importantly, we compared the predictivity of CWN and NEP in terms of explaining the intention of environmental behavior (IEB). By doing this survey, we aim to answer the research question: Can CWN predict Taiwanese and Japanese undergraduates' IEB better than NEP?

\section{Method}

\section{Data Collection}

\section{1). Research Participants}

This cross-country CWN survey's main participants were undergraduate students from Central Taiwan and Tohoku (north-eastern) and Kansai (southern-central) regions in Japan. A total of 178 Taiwanese undergraduates joined this survey from the National Taichung University of Education, National Taichung University of Science and Technology, and Providence University. In Japan, 124 undergraduates from the Aomori University and Ritsumeikan University participated in this research. The total number of the sample was 302. Most undergraduates were 19 to 20 years old and lived in suburban and urban areas. The majors of Taiwanese undergraduates at university were more diverse than those of Japanese undergraduates. It is interesting to note that $66.9 \%$ of Taiwanese undergraduates went outdoors with family members, compared to only $26.6 \%$ of Japanese undergraduates. More demographic information was analyzed in Appendix 1. 


\section{2). Questionnaire Design and Reliability}

According to research questions, we designed a questionnaire that contained four partsdemographic information, environmental attitude (the tendency of agreement on New Ecological Paradigm, NEP), CWN, and IEB. Except for the demographic items, NEP, CWN, and IEB were measured by a six-point Likert scale ( 1 being strongly disagree and 6 being strongly agree). Please refer to Appendix 2 and 3 for complete scales.

Among all the demographic items, we particularly wanted to know if undergraduates ever went outdoors with family members (mainly parents and siblings). If they did outdoor activities with family members, the family item would be coded as 1 . Otherwise, it would be coded as 0. Further, we chose Dunlap et al.'s (2000) NEP because scholars widely adopted it in many countries to measure environmental attitude. The reliability (Cronbach's alpha) was .83 when originally tested in American adults. To reduce the threat to scale validity in non-western countries, we introduced the Connection with Nature Scale for Taiwanese adolescents to collect information about how close undergraduates felt with nature in multiple psychological dimensions (Tseng 2019). It contained constructs of sensory experience, psychological benefit, and the symbolical importance of nature. The original Cronbach's alpha of the whole scale was .90 when tested it on Taiwanese teenagers.

Regarding the measurement of IEB, as young adults, undergraduates should have the autonomy and ability to conduct more complicated behaviors than other younger K-12 graders. Therefore, we focused on three more difficult behaviors: persuasion (persuading family, classmates, or friends to protect environments), civic engagement (participating in clubs or organizations as volunteer or member to protect environments), and politics and law actions (supporting politicians, congress members, or officials to protect the environment). We selected IEB items that have been commonly used in national environmental literacy surveys in the U.S. (Zhu 2015).

We first completed a Chinese questionnaire. The questionnaire's scales and items were already reviewed and revised by scholars with expertise in environmental education, psychometrics, and statistics from previous research (Tseng 2019, 2020). The first author translated the Chinese questionnaire into English, after which it was translated into Japanese by two other authors. The first author also invited a Taiwanese researcher who gained a doctoral degree at the Nagoya Institute of Technology in Japan to check the quality of the Chinese-Japanese translation. The whole process had assured the content and face validity of the questionnaire. Regarding the reliability, we have listed Cronbach's alpha of each main variable and subordinate constructs in Appendix 4. Almost all the scales' reliability (including subscales) of the NEP, CWN, and IEB was higher than the accepted level of .60. Only the reliability of CWN-importance of nature in Japan was lower (.55).

To avoid respondent's social desirability that might cause measuring bias, we explicitly informed the respondents both orally and in written form in the survey process that there is no standard answer to those survey questions and we do not expect them to perform particular tendency. We told the respondents to choose what they felt most appropriate according to their feelings, thoughts or experiences. 


\section{Data Analysis}

We used SPSS (version 27) to analyze data. According to the research purposes, we computed demographic information in Appendix 1. To understand if there was any significant difference in the NEP, CWN, and IEB scores between Taiwan and Japan, we conducted an independent sample t-test. Furthermore, we adopted multiple regression analysis separately in samples of Taiwan and Japan to verify if NEP and CWN could significantly predict IEB as most previous research assumed and compared CWN and NEP's predictivity.

\section{Result}

\section{Descriptive statistics and score difference between Taiwan and Japan}

Taiwanese undergraduates seemed to perform more actively in CWN, NEP, and IEB than Japanese undergraduates. Taiwanese undergraduates' mean scores of the entire CWN and two constructs were significantly higher than those of Japanese undergraduates. Only the CWN-psychological benefit score was the same in both countries. There was a similar tendency in NEP and IEB (including the entire IEB and two constructs of persuasion, politics, and law action). Only the IEB of civic engagement showed no statistical difference between the countries. In addition, there was no statistical difference in gender (male, female), residential areas (urban, suburban, and countryside), and frequencies of outdoor activities accompanied by family in Taiwanese undergraduates' whole $\mathrm{CWN}$ and its three constructs. However, Japanese undergraduates accompanied by the family had significantly higher scores in $\mathrm{CWN}$-sensory experience $(\mathrm{M}=4,58>4.08, \mathrm{p}<.05)$.

Table 1 Descriptive statistics and independent sample t-test

\begin{tabular}{|c|c|c|c|c|c|c|}
\hline & \multicolumn{2}{|c|}{ Mean (SD) } & \multirow[b]{2}{*}{$d f$} & \multirow[b]{2}{*}{$t$} & \multirow[b]{2}{*}{$p$} & \multirow[b]{2}{*}{$\begin{array}{c}\text { effect } \\
\text { size }(d)\end{array}$} \\
\hline & $\begin{array}{c}\text { Taiwan } \\
(\mathrm{N}=178)\end{array}$ & $\begin{array}{c}\text { Japan } \\
(\mathrm{N}=124)\end{array}$ & & & & \\
\hline NEP & $4.68(.71)$ & $3.97(.48)$ & 300 & 10.40 & $<.001$ & 1.13 \\
\hline CWN (whole scale) & $4.52(.82)$ & $4.14(.83)$ & 300 & 4.00 & $<.001$ & .48 \\
\hline CWN-sensory experience & $4.74(.86)$ & $4.45(.99)$ & 300 & 2.72 & .007 & .32 \\
\hline CWN-psychological benefit & $4.42(.94)$ & $4.42(.94)$ & 300 & 0.01 & .993 & .001 \\
\hline CWN-importance of nature & $4.27(.97)$ & $3.34(1.02)$ & 300 & 8.00 & $<.001$ & .94 \\
\hline IEB (whole scale) & $4.22(.86)$ & $3.60(1.09)$ & 224 & 5.34 & $<.001$ & .65 \\
\hline IEB-persuasion & $4.81(.89)$ & $3.88(1.24)$ & 208 & 7.20 & $<.001$ & .89 \\
\hline IEB-civic engagement & $3.87(1.05)$ & $3.72(1.16)$ & 300 & 1.25 & .214 & .14 \\
\hline IEB-politics and law & $4.04(1.02)$ & $3.29(1.19)$ & 239 & 5.68 & $<.001$ & .69 \\
\hline
\end{tabular}

\section{CWN predictability to the IEB (compared with NEP)}

\section{1). The prediction of NEP and CWN to the entire IEB}

When we compared CWN and NEP's predictivity to the entire IEB in both Taiwanese and Japanese samples, we found CWN was a more powerful predictor than NEP. In addition, the regression coefficient of CWN in the Taiwanese sample was higher than that in the Japanese sample. Besides, the NEP was not a significant predictor in the Japanese sample. 
Table 2-1 Multiple regression to the entire IEB in Taiwan

\begin{tabular}{|c|c|c|c|c|c|}
\hline \multirow[t]{2}{*}{ Model } & \multicolumn{2}{|c|}{$\begin{array}{c}\text { Unstandardized } \\
\text { coefficients }\end{array}$} & \multirow{2}{*}{$\begin{array}{c}\begin{array}{c}\text { Standardized } \\
\text { coefficients }\end{array} \\
\beta \\
\end{array}$} & \multirow[t]{2}{*}{$t$} & \multirow[t]{2}{*}{$p$} \\
\hline & $B$ & $S E$ & & & \\
\hline (intercept) & .46 & .41 & & 1.11 & .27 \\
\hline NEP & .27 & .07 & .22 & 3.61 & $<.001$ \\
\hline CWN (whole scale) & .55 & .06 & .53 & 8.61 & $<.001$ \\
\hline \multicolumn{6}{|c|}{$\begin{array}{l}\mathrm{R}=.61^{\mathrm{a}} \quad \mathrm{R}^{2}=.37 \quad \Delta \mathrm{R}^{2}=.36 \\
\text { ion of environmental behaviors (IEB) }\end{array}$} \\
\hline
\end{tabular}

Table 2-2 Multiple regression to entire IEB in Japan

\begin{tabular}{|c|c|c|c|c|c|}
\hline \multirow[t]{2}{*}{ Model } & \multicolumn{2}{|c|}{$\begin{array}{l}\text { Unstandardized } \\
\text { coefficients }\end{array}$} & \multirow{2}{*}{$\begin{array}{c}\begin{array}{c}\text { Standardized } \\
\text { coefficients }\end{array} \\
\beta\end{array}$} & \multirow[t]{2}{*}{$t$} & \multirow[t]{2}{*}{$p$} \\
\hline & $B$ & $S E$ & & & \\
\hline (intercept) & 1.15 & .79 & & 1.46 & .148 \\
\hline NEP & .05 & .20 & .02 & .27 & .79 \\
\hline CWN (whole scale) & .54 & .11 & .41 & 4.764 & $<.001$ \\
\hline \multicolumn{6}{|c|}{$\begin{array}{l}\mathrm{R}=.42^{\mathrm{a}} \quad \mathrm{R}^{2}=.17 \quad \Delta \mathrm{R}^{2}=.16 \\
\text { ion of environmental behaviors (IEB) }\end{array}$} \\
\hline
\end{tabular}

\section{2). The prediction of three CWN constructs and NEP to three IEBs}

To further understand which CWN could best predict different IEBs, we made three CWN constructs as independent variables to predict each kind of IEB. In addition, we kept NEP an independent variable to compare its predictive power with three CWN constructs. All detailed results are shown in Tables 3-1 to 5-2.

For Taiwanese undergraduates' persuasive IEB, sensory experience $(\beta=28, \mathrm{p}<.01)$ and NEP $(\beta=21, \mathrm{p}<.01)$ were two significant predictors, and the adjusted total variance explained was .30 . For Japanese undergraduates, the sensory experience was the only influential factor $(\beta=40, \mathrm{p}<.01)$, and the adjusted $\mathrm{R}^{2}$ was .18 . When predicting the IEB of civic engagement, only the importance of nature $(\beta=41, \mathrm{p}<.001)$ and the $\operatorname{NEP}(\beta=20, \mathrm{p}<.01)$ were significant predictors in the Taiwanese sample, and the adjusted total variance explained was .36. Meanwhile, in Japan, neither NEP nor any of the three CWN constructs could predict civic engagement. In terms of IEB of political and law action, only the importance of nature was influential to Taiwanese undergraduates $(\beta=.23$, $\left.\mathrm{p}<.05, \triangle \mathrm{R}^{2}=.20\right)$. In contrast, the sensory experience was the only significant factor for Japanese undergraduates' IEB of political and law action $\left(\beta=.37, \mathrm{p}<.01, \triangle \mathrm{R}^{2}=.11\right)$.

In sum, the sensory experience was the best predictor of persuasive IEB in both countries. It was also the only significant factor to predict Japanese undergraduates' IEB to political and law action. Comparatively, the importance of nature was the only $\mathrm{CWN}$ construct that can predict Taiwanese undergraduates' IEB to civic engagement and political and law action. It is worth noting that none of the three CWN constructs could predict Japanese undergraduates' IEB of civic engagement. Similarly, the NEP could not predict any of the three IEBs in the Japanese sample (but the NEP can influence the IEB of civic engagement, political and law action in the Taiwanese samples). Among all three CWN constructs, the psychological benefit seemed the less important factor because it could not predict any of the three IEBs. 
Table 3-1 Multiple regression to IEB-persuasion in Taiwan

\begin{tabular}{|c|c|c|c|c|c|}
\hline \multirow[t]{2}{*}{ Model } & \multicolumn{2}{|c|}{$\begin{array}{c}\text { Unstandardized } \\
\text { coefficients }\end{array}$} & \multirow{2}{*}{$\begin{array}{c}\begin{array}{c}\text { Standardized } \\
\text { coefficients }\end{array} \\
\beta \\
\end{array}$} & \multirow[t]{2}{*}{$t$} & \multirow[t]{2}{*}{$p$} \\
\hline & $B$ & $S E$ & & & \\
\hline (intercept) & 1.17 & .46 & & 2.54 & .01 \\
\hline NEP & .27 & .08 & .21 & 3.21 & .002 \\
\hline CWN-sensory experience & .29 & .09 & .28 & 3.09 & .002 \\
\hline CWN-psychological benefit & .10 & .11 & .10 & .89 & .38 \\
\hline $\mathrm{CWN}$-importance of nature & .14 & .10 & .15 & 1.49 & .14 \\
\hline
\end{tabular}

Table 3-2 Multiple regression to IEB-persuasion in Japan

\begin{tabular}{|c|c|c|c|c|c|}
\hline \multirow[t]{2}{*}{ Model } & \multicolumn{2}{|c|}{$\begin{array}{c}\text { Unstandardized } \\
\text { coefficients }\end{array}$} & \multirow{2}{*}{$\begin{array}{c}\begin{array}{c}\text { Standardized } \\
\text { coefficients }\end{array} \\
\beta \\
\end{array}$} & \multirow[t]{2}{*}{$t$} & \multirow[t]{2}{*}{$p$} \\
\hline & $B$ & $S E$ & & & \\
\hline (intercept) & .78 & .89 & & .88 & .38 \\
\hline NEP & .15 & .22 & .06 & .69 & .49 \\
\hline CWN-sensory experience & .50 & .15 & .40 & 3.25 & .001 \\
\hline CWN-psychological benefit & .003 & .16 & .003 & .02 & .98 \\
\hline CWN-importance of nature & .07 & .12 & .06 & .64 & .52 \\
\hline
\end{tabular}

Table 4-1 Multiple regression to IEB-civic engagement in Taiwan

\begin{tabular}{|c|c|c|c|c|c|}
\hline \multirow[t]{2}{*}{ Model } & \multicolumn{2}{|c|}{$\begin{array}{l}\text { Unstandardized } \\
\text { coefficients }\end{array}$} & \multirow{2}{*}{$\begin{array}{c}\begin{array}{c}\text { Standardized } \\
\text { coefficients }\end{array} \\
\beta\end{array}$} & \multirow[t]{2}{*}{$t$} & \multirow[t]{2}{*}{$p$} \\
\hline & $B$ & $S E$ & & & \\
\hline (intercept) & -.32 & .52 & & -.61 & .55 \\
\hline NEP & .30 & .09 & .20 & 3.17 & .002 \\
\hline CWN-sensory experience & .12 & .11 & .10 & 1.17 & .25 \\
\hline CWN-psychological benefit & .07 & .12 & .07 & .61 & .54 \\
\hline CWN-importance of nature & .44 & .11 & .41 & 4.16 & $<.001$ \\
\hline \multicolumn{6}{|c|}{$\begin{array}{c}\mathrm{R}=.62^{\mathrm{a}} \quad \mathrm{R}^{2}=.38 \Delta \mathrm{R}^{2}=.36 \\
\mathrm{a}=\mathrm{IEB} \text {-civic engagement }\end{array}$} \\
\hline
\end{tabular}

Table 4-2 Multiple regression to IEB-civic engagement in Japan

\begin{tabular}{|c|c|c|c|c|c|}
\hline \multirow[t]{2}{*}{ Model } & \multicolumn{2}{|c|}{$\begin{array}{l}\text { Unstandardized } \\
\text { coefficients }\end{array}$} & \multirow{2}{*}{$\begin{array}{c}\begin{array}{c}\text { Standardized } \\
\text { coefficients }\end{array} \\
\beta\end{array}$} & \multirow[t]{2}{*}{$t$} & \multirow[t]{2}{*}{$p$} \\
\hline & $B$ & $S E$ & & & \\
\hline (intercept) & 1.42 & .85 & & 1.67 & .10 \\
\hline NEP & -.01 & .21 & -.004 & -.05 & .96 \\
\hline CWN-sensory experience & .28 & .15 & .24 & 1.92 & .06 \\
\hline CWN-psychological benefit & .26 & .16 & .21 & 1.70 & .09 \\
\hline CWN-importance of nature & -.02 & .11 & -.02 & -.17 & .87 \\
\hline \multicolumn{6}{|c|}{$\begin{array}{c}\mathrm{R}=.41^{\mathrm{a}} \mathrm{R}^{2}=.17 \Delta \mathrm{R}^{2}=.14 \\
\mathrm{a}=\mathrm{IEB} \text {-civic engagement }\end{array}$} \\
\hline
\end{tabular}


Table 5-1 Multiple regression to IEB-political and law action in Taiwan

\begin{tabular}{|c|c|c|c|c|c|}
\hline \multirow[t]{2}{*}{ Model } & \multicolumn{2}{|c|}{$\begin{array}{l}\text { Unstandardized } \\
\text { coefficients }\end{array}$} & \multirow{2}{*}{$\begin{array}{c}\begin{array}{c}\text { Standardized } \\
\text { coefficients }\end{array} \\
\beta\end{array}$} & \multirow[t]{2}{*}{$t$} & \multirow[t]{2}{*}{$p$} \\
\hline & $B$ & $S E$ & & & \\
\hline (intercept) & .87 & .57 & & 1.53 & .13 \\
\hline NEP & .19 & .10 & .13 & 1.83 & .07 \\
\hline CWN-sensory experience & .18 & .12 & .15 & 1.54 & .13 \\
\hline CWN-psychological benefit & .09 & .13 & .09 & .71 & .48 \\
\hline $\mathrm{CWN}$-importance of nature & .25 & .12 & .23 & 2.13 & .04 \\
\hline \multicolumn{6}{|c|}{$\begin{array}{c}\mathrm{R}=.47^{\mathrm{a}} \quad \mathrm{R}^{2}=.22 \quad \Delta \mathrm{R}^{2}=.20 \\
\mathrm{a}=\mathrm{IEB}-\text { politics and law }\end{array}$} \\
\hline
\end{tabular}

Table 5-2 Multiple regression to IEB-political and law action in Japan

\begin{tabular}{|c|c|c|c|c|c|}
\hline \multirow[t]{2}{*}{ Model } & \multicolumn{2}{|c|}{$\begin{array}{c}\text { Unstandardized } \\
\text { coefficients }\end{array}$} & \multirow{2}{*}{$\begin{array}{c}\begin{array}{c}\text { Standardized } \\
\text { coefficients }\end{array} \\
\beta\end{array}$} & \multirow[t]{2}{*}{$t$} & \multirow[t]{2}{*}{$p$} \\
\hline & $B$ & $S E$ & & & \\
\hline (intercept) & 1.32 & .89 & & 1.49 & .14 \\
\hline NEP & $<.001$ & .22 & $<.001$ & -.001 & 1.00 \\
\hline CWN-sensory experience & .44 & .15 & .37 & 2.87 & .01 \\
\hline CWN-psychological benefit & -.05 & .16 & -.04 & -.30 & .77 \\
\hline CWN-importance of nature & .07 & .11 & .06 & .63 & .53 \\
\hline \multicolumn{6}{|c|}{$\begin{array}{c}\mathrm{R}=.37^{\mathrm{a}} \mathrm{R}^{2}=.14 \Delta \mathrm{R}^{2}=.11 \\
\mathrm{a}=\text { IEB-politics and law }\end{array}$} \\
\hline
\end{tabular}

\section{Discussion and Conclusion}

Will CWN differ in gender? Some studies asserted that females had higher CWN than males (e.g., Dornhoff et al.'s survey on high school students in Germany in 2019). The other studies supported that males' CWN was higher (e.g., study by Larson et al. 2019 conducted in the U.S). However, following the result of studies in Turkish, British, and Spanish (Ahmetoglu 2019, Bragg et al. 2013, Musitu-Ferrer et al. 2019), our analysis in Taiwan and Japan discovered no gender differences. Bedsides, according to what the SLE research has indicated, the family was another important facilitator to cultivate adults' EB by encouraging or accompanying children to play outdoors (Chawla 2007, D'Amore and Chawla 2020). Though our finding showed that Japanese undergraduates who were accompanied by family members outdoors had significantly higher CWN-sensory experiences, we found no such difference in the Taiwanese sample. This result remains a puzzle for us. Concerning the influence of geographic locations (and maybe cultural contexts) on CWN, Whitburn et al. (2019) reported no moderation effect through a meta-analysis from 37 studies. That is, CWN might not be culturally patterned so far. However, it was still worthy of exploring any cultural clues that distinguish the CWN level in Taiwan and Japan.

When Whitburn et al. (2019) used Comprehensive Meta-Analysis software to analyze 37 CWN studies in diverse countries $(n=13,237)$, they found a positive and significant association between CWN and EB ( $\mathrm{r}=0.42,95 \%$ CI $0.36,0.47, \mathrm{p}<.001)$ in a random-effects model. This relationship could hold across gender and geographic location, regardless of the instrument they adopted to measure CWN and EB. Our research also partially confirmed Whitburn et al.'s 
(2009) findings and the studies reviewed in the introduction because CWN was the only common factor that can predict IEB in Taiwan and Japan. This result was also consistent with what Zylstra et al. (2014) and Chawla (2020) had concluded after they reviewed numerous papers. They discovered that children, adolescents, and adults with higher levels of nature connection showed greater willingness to conserve nature and applied pro-environmental behaviors such as energy saving, recycling, environmental volunteering, and talking with others about the importance of environmental protection. Although this research adopted a new Asian scale to measure $\mathrm{CWN}$, in general, our findings replicate what previous western studies have verified, namely that $\mathrm{CWN}$ is a prominent psychological motivator to people's pro-environmental behaviors (including intention).

Our research further revealed interesting details about what kind of CWN better predicted different types of IEB and compared CWN and NEP's predictivity in Taiwan and Japan separately. The overall result indicated that CWN was a much more powerful predictor than NEP to influence Taiwanese and Japanese undergraduates' IEBs. However, CWN seemed more influential in Taiwan. For Taiwanese undergraduates, two CWN constructs - sensory experience and the importance of nature were key predictors to all three IEBs. In contrast, only sensory experience can predict Japanese undergraduates' IEB in persuasion, political and law action.

We understand that there are several limitation to our research. Firstly, we were not able to reveal what types of cultural characteristics affected NEP and CWN and overall IEB. Future studies should look into how cultural, social, and demographic differences between Taiwan and Japan affect their perceptions and behaviors. In addition, further studies would be necessary to understand such as what types and frequency of outdoor activities students daily engage in to interpret why there were significant difference between Taiwanese and Japanese students in terms of CWN and NEP. Furthermore, since there was a decent difference in terms of outdoor experiences with family between Taiwanese and Japanese students, future research could include this factor as independent variable to predict influence of family experience on CWN and IEB. Since more nursery school/ pre-school/kindergarten are providing nature experience programs today, future surveys might also need to explore the influences of outdoor experiences from those school system. We also understand that only certain types of environmental behavioral intentions are measured in our survey (especially focusing on persuading and political behaviors), and future research could look into other types of environmental behaviors and intentions (e.g., saving electricity, bringing my bag and cup) and verify if the relationship between CWN and IEB are still obvious. Finally, if $\mathrm{CWN}$ is so influential to $\mathrm{EBs}$, how can we figure out the best strategies to design effective educational practices to improve undergraduates' CWN? We will need more research to answer all those fascinating questions in the future.

\section{References}

Ahmetoglu, E. 2019. The Contributions of Familial and Environmental Factors on Children's Connection with Nature and Outdoor Activities. Early Childhood Development and Care, 189(2): 233-243.

Bragg, R., Wood, C., Barton, J., and Pretty, J. 2013. Measuring Connection to Nature in Children 
8-12: A Robust Methodology for the Royal Society for the Protection of Birds. Colchester, UK: Essex Sustainability Institute and School of Biological Sciences.

Cagle, N. L. 2018. Changes in Experiences with Nature Through the Lives of Environmentally Committed University Faculty. Environmental Education Research 24(6): 889-898. doi: http://dx.doi.org/10.1080/13504622.2017.1342116

Chawla, L. 2007. Childhood Experiences Associated with Care for the Natural World. Children, Youth and Environments, 17(4): 144-170.

Chawla, L., and Derr, V. 2012. The Development of Conservation Behaviors in Childhood and Youth. In The Oxford handbook of environmental and conservation psychology, edited by Clayton, S. D., 527-555. New York, NY: Oxford University Press.

Chawla, L. 2020. Helping Students Cope with Environmental Change and Take Constructive Civic Action. Green Schools Catalyst Quarterly, 7(1): 44-57.

Clayton S. 2003. Environmental Identity: A Conceptual and Operational Definition. Identity and the Natural Environment: The Psychological Significance of Nature, edited by Clayton S., and Opotow S., 45-65. MIT Press, Cambridge, Massachusetts.

D'Amore, C., and Chawla, L. 2020. Significant Life Experiences that Connect Children with Nature: A Research Review and Applications to A Family Nature Club. In Research handbook on Childhoodnature, edited by A. Cutter-Mackenzie-Knowles, K. Malone, \& E. Barratt Hacking (Eds.), 799-825. Cham, Switzerland: Springer Nature Switzerland.

Dornhoff, M., Sothmann, J.-N., Fiebelkorn, F., and Menzel, S. 2019. Nature Relatedness and Environmental Concern of Young People in Ecuador and Germany. Frontiers in Psychology, 10: 453.doi: https://doi.org/10.3389/fpsygg.2019.00453

Dunlap, R. E., Van Liere, K. D., Mertig, A. G., \& Emmet Jones, R. (2000). Measuring endorsement of the new ecological paradigm: A revised NEP scale. Journal of Social Issues, 56(3), 425-442. doi: https://doi.org/10.1111/0022-4537.00176

Hines J. M., Hungerford H., and Tomera A. N. 1987. Analysis and Synthesis of Research on Responsible Environmental Behaviour: A Meta-Analysis. Journal of Environmental Education, 18: 1-8.

Kals E, Schumacher D, and Montada L. 1999. Emotional Affinity Toward Nature as A Motivational Basis to Protect Nature. Environment and Behavior, 31: 178-202.

Larson, D. F., Stevenson, K. T., Peterson, M. N., Carrier, S. J., Seekamp, E., and Strnad, R. 2019. Evaluating Climate Change Concern and Behaviors in the Family Context. Environmental Education Research, 25(5): 678-690. doi: https://doi.org/10.1080/13504 622.2018.1564248

Louv, R. 2005. Last Child in the Woods. Chapel Hill, NC: Algonquin Books.

Mayer FS, and Frantz CM. 2004. The Connectedness to Nature Scale: A Measure of Individuals' Feeling in Community with Nature. Journal of Environmental Psychology, 24: 503-515.

Musitu-Ferrer, D., Léon-Moreno, C., Callejas-Jerónimo, J. E., Esteban- Ibáñez, M., and Musitu-Ochoa, G. 2019. Relationships between Parent Socialization Styles, Empathy and Connectedness with Nature: Their Implications in Environmentalism. International Journal of Environmental Research and Public Health, 16. doi: https://doi.org/10.3390/ijerph1614 $\underline{2461}$ 
Nisbet, E. K., Zelenski, J. M., and Murphy, S. A. 2009. The Nature Relatedness Scale Linking Individuals' Connection with Nature to Environmental Concern and Behavior. Environment and Behavior, 41: 715-740. doi: http://dx.doi.org/10.1177/0013916508318748

Olivos, P., Aragonés, J. I. and Amérigo, M. 2011. The Connectedness to Nature Scale and Its Relationship with Environmental Beliefs and Identity. International Journal of Hispanic Psychology, 4(1): 5-19.

Pasca, L., Coello, M. T., Aragonés, J. I., and Frantz, C. M. 2018. The Equivalence of Measures on The Connectedness to Nature Scale: A Comparison between Ordinal Methods of DIF Detection. PLoS ONE, 13(11). doi: https://doi.org/10.1371/journal.pone.0207739

Schultz, P. W. 2002. Inclusion with Nature: The Psychology of Human-Nature Relations. In Psychology of Sustainable Development, edited by P. Schmuck \& W. P. Schultz (Eds.), 6178. Boston, MA: Springer.

Tam, K.-P. 2013. Concepts and Measures Related to Connection to Nature: Similarities and Differences. Journal of Environmental Psychology, 34: 64-78. doi: https://doi.org/10.1016/j. jenvp.2013.01.004

Tseng, Y. C., and Wang, S. M. 2020. Understanding Taiwanese Adolescents' Connections with Nature: Rethinking Conventional Definitions and Scales for Environmental Education. Environmental Education Research, 26(1): 115- 129. doi: http://dx.doi.org/10.1080/135046 $\underline{22.2019 .1668354}$

Tseng, Y. C. 2019. The Development of Connection with Nature Scale for Junior-High-School Adolescents. Chinese Journal of Science Education, 27(4): 323-345. doi: http://dx.doi.org/10.6173/CJSE.201912 27(4).0006. (in Chinese).

Tseng, Y. C. 2020. An Explorative Research on the Relationships among Taiwanese Adolescents' Significant Life Experiences and Environmental Behaviors with the Mediation of Connection with Nature. Chinese Journal of Science Education,28(3): 223-254. doi: http://dx.doi. org/10.6173/CJSE.202009 28(3).0002. (in Chinese).

Whitburn, J., Linklater, W. L., and Milfont, T. L. 2019. Exposure to Urban Nature and Tree Planting Are Related to Pro-Environmental Behavior via Connection to Nature, the Use of Nature for Psychological Restoration, and Environmental Attitudes. Environment and Behavior, 51(7): 787-810. doi: http://dx.doi.org/10.1177/0013916517751009

Whitburn, J., Linklater, W., and Abrahamse, W. 2020. Meta-Analysis of Human Connection to Nature and Proenvironmental Behavior. Conservation Biology, 34(1): 180-193. doi: https:// doi.org/10.1111/cobi.13381

Zhu, Y. (2015). An assessment of environmental literacy among undergraduate students at two national universities in Hubei province, China. Unpublished doctoral dissertation, Florida Institute of Technology, Melbourne, FL.

Zylstra, M. J., Esler, K. J., Knight, A. T., and LeGrange, L. L. 2014. Connectedness as A Core Conservation Concern: An Interdisciplinary Review of Theory and A Call for Practice. Springer Science Reviews, 2: 119-143. doi: https://doi.org/10.1007/s4036 2-014-0021-3 


\section{Appendix}

Appendix 1 Demographics of undergraduates in Taiwan $(\mathrm{N}=178)$ and Japan $(\mathrm{N}=124)$

\begin{tabular}{|c|c|c|c|c|c|}
\hline \multirow[t]{2}{*}{ Demographic items } & \multirow[t]{2}{*}{ Category } & \multicolumn{2}{|c|}{$\begin{array}{l}\text { Taiwan } \\
(\mathrm{N}=178)\end{array}$} & \multicolumn{2}{|c|}{$\begin{array}{l}\text { Japan } \\
(\mathrm{N}=124)\end{array}$} \\
\hline & & $\mathrm{N}$ & $\%$ & $\mathrm{~N}$ & $\%$ \\
\hline \multirow[t]{6}{*}{ Age } & 18 & 1 & $.6 \%$ & 12 & $9.7 \%$ \\
\hline & 19 & 111 & $62.4 \%$ & 43 & $34.7 \%$ \\
\hline & 20 & 40 & $22.5 \%$ & 37 & $29.8 \%$ \\
\hline & 21 & 14 & $7.9 \%$ & 16 & $12.9 \%$ \\
\hline & 22 & 7 & $3.9 \%$ & 10 & $8.1 \%$ \\
\hline & over 23 & 3 & $1.7 \%$ & 2 & $1.6 \%$ \\
\hline \multirow[t]{2}{*}{ Gender } & Male & 91 & $51.1 \%$ & 68 & $54.8 \%$ \\
\hline & Female & 86 & $48.3 \%$ & 48 & $38.7 \%$ \\
\hline \multirow[t]{3}{*}{ Residential areas } & Countryside & 38 & $21.3 \%$ & 37 & $29.8 \%$ \\
\hline & Suburb & 73 & $41.0 \%$ & 49 & $39.5 \%$ \\
\hline & Urban & 67 & $37.6 \%$ & 31 & $25.0 \%$ \\
\hline University & Social Science & 24 & $13.5 \%$ & 90 & $72.6 \%$ \\
\hline \multirow[t]{4}{*}{ Major } & Humanities and Art/Design & 59 & $33.1 \%$ & - & - \\
\hline & Management & 19 & $10.7 \%$ & 34 & $27.4 \%$ \\
\hline & Computer Science/Electrical Engineering & 36 & $20.2 \%$ & - & - \\
\hline & Natural Sciences/Mathematics & 40 & $22.5 \%$ & - & - \\
\hline \multirow{2}{*}{$\begin{array}{l}\text { Outdoor } \\
\text { activities }\end{array}$} & Without family & 59 & $33.1 \%$ & 91 & $73.4 \%$ \\
\hline & With family & 119 & $66.9 \%$ & 33 & $26.6 \%$ \\
\hline
\end{tabular}

\section{Appendix 2 Descriptive statistics of CWN scale in both Taiwanese and Japanese samples}

\begin{tabular}{lcc}
\hline & \multicolumn{2}{c}{$\mathrm{M}(\mathrm{SD})$} \\
\cline { 2 - 3 } Items & $\begin{array}{c}\text { Taiwan } \\
(\mathrm{N}=178)\end{array}$ & $\begin{array}{c}\text { Japan } \\
(\mathrm{N}=124)\end{array}$ \\
\hline CWN-sensory experience & & $4.38(1.25)$ \\
4)I enjoy hearing different sounds in nature. & $4.27(1.28)$ & $4.29(1.47)$ \\
5)I enjoy watching the clouds moving across the sky. & $5.31(.90)$ & $3.98(1.47)$ \\
6)I enjoy observing animals when being outdoors. & $4.39(1.28)$ & $4.73(1.22)$ \\
7)I enjoy smelling fresh air when being in nature. & $4.79(1.11)$ & $4.85(1.07)$ \\
8)I enjoy sitting or lying down on the grassland. & $4.93(1.00)$ & $4.85(1.07)$ \\
\hline CWN-psychological benefit & $4.93(1.00)$ & $4.75(1.13)$ \\
1)I feel relaxed when being in nature. & $3.84(1.23)$ & $3.65(1.43)$ \\
2)I think nature is important to who I am. & $4.49(1.26)$ & $3.19(1.27)$ \\
3)I think about my day when I have quiet time in nature. & & $3.37(1.34)$ \\
\hline CWN-importance of nature & $3.63(1.34)$ & $3.46(1.59)$ \\
9)I feel I am missing something if not being able to spend time in nature. & $4.64(1.16)$ & $4.53(1.24)$ \\
10)I feel sad when seeing new shopping malls replacing natural areas. & & \\
11)I feel like there is something bigger than me when being in nature. & & \\
\hline
\end{tabular}




\section{Appendix 3 Descriptive statistics of IEB scale in both Taiwanese and Japanese samples}

\begin{tabular}{|c|c|c|}
\hline \multirow[b]{2}{*}{ How much are you willing to conduct the following pro-environmental behaviors? } & \multicolumn{2}{|c|}{ Mean (SD) } \\
\hline & $\begin{array}{c}\text { Taiwan } \\
(\mathrm{N}=178)\end{array}$ & $\begin{array}{c}\text { Japan } \\
(\mathrm{N}=124)\end{array}$ \\
\hline \multicolumn{3}{|l|}{ IEB-persuasion } \\
\hline 3)Encouraging others to recycle and reuse stuff. & $4.99(.97)$ & $4.13(1.34)$ \\
\hline 4)Actively introducing strategies to conserve natural resources to family and friends. & $4.89(1.03)$ & $3.90(1.40)$ \\
\hline $\begin{array}{l}\text { 7)Encouraging or persuading others to take actions to solve or prevent environmental } \\
\text { problems. }\end{array}$ & $4.56(1.10)$ & $3.60(1.45)$ \\
\hline \multicolumn{3}{|l|}{ IEB-civic engagement } \\
\hline 1)Joining nature conservation-related NPOs or student clubs. & $3.51(1.27)$ & $4.02(1.30)$ \\
\hline 2)Donating money to nature conservation-related NPOs. & $3.73(1.36)$ & $3.78(1.34)$ \\
\hline 5)Participating in petitions related to issues about nature conservation. & $4.38(1.23)$ & $3.34(1.52)$ \\
\hline \multicolumn{3}{|l|}{ IEB-politics and law } \\
\hline 6)Participating in public hearings related to issues about nature conservation. & $3.69(1.25)$ & $3.16(1.39)$ \\
\hline 8)Supporting political parties that advocate environmental protection policies. & $4.00(1.35)$ & $3.44(1.47)$ \\
\hline 9)Reporting violations of environmental laws to the official environmental organizations. & $4.26(1.25)$ & $3.15(1.36)$ \\
\hline 10)Supporting victims to take legal actions against environmental destruction. & $4.21(1.27)$ & $3.43(1.33)$ \\
\hline
\end{tabular}

Appendix 4 Reliability of all variables in both Taiwanese and Japanese samples

\begin{tabular}{lll}
\hline Variable and Constructs & Taiwan & Japan \\
\hline NEP & .84 & .72 \\
CWN (whole scale) & .89 & .89 \\
CWN-sensory experience & .83 & .81 \\
CWN-psychological benefit & .73 & .65 \\
CWN-importance of nature & .67 & .55 \\
IEB (whole scale) & .89 & .93 \\
IEB-persuasion & .82 & .87 \\
IEB-civic engagement & .75 & .78 \\
IEB-politics and law & .81 & .88 \\
\hline
\end{tabular}

